\title{
What Must We Know and Know How to Do for Implementation During the PENTA UC School Program? A View from the Teachers
}

\section{¿Qué debemos saber y saber hacer para implementar el Programa PENTA UC Escolar? Una mirada desde los profesores}

Recibido: octubre 27 de 2010 | Revisado: junio 11 de 2011 | Aceptado: diciembre 15 de 2011

\author{
Elsa Piedad Cabrera-Murcia * \\ Pontificia Universidad Católica de Chile, Chile
}

SICI: 1657-9267(201209)11:3<815:WMWKAK>2.0.TX;2-W

Para citar este artículo. Cabrera-Murcia, E. P. (2012). What Must We Know and Know how to do for Implementation during the PENTA UC School Program? A view from the teachers. Universitas Psychologica, 11(3), 815-827.

\footnotetext{
Profesora asistente adjunta de la Facultad de Edu-
} cación.E-mail: epcabrer@uc.cl

\begin{abstract}
A B S T R A C T
This study explored what should be known, by a teacher of talented children, when implementing the PENTA UC School program. This study included a sample of 18 educators directly involved in the implementation process of this enrichment program. Teachers established bridges between verbalized knowledge and their pedagogic practice, recognizing know and know-how as two fundamental spheres of knowledge for the implementation of this program. The results show that these spheres traverse five different dimensions: planning, implementation, evaluation, learning environment, and collaborative work; which, in conjunction, allow the teacher to apply a differentiated instruction, taking into consideration the particular learning paces and characteristics of talented children. Furthermore, the need to consider these spheres in teacher's preparation programs was confirmed. Key words authors

Know, Know-how-to-do, Teachers, Talent Education.

Key words plus

Educators, Gifted Children, School, Qualitative Research.
\end{abstract}

\section{RESUMEN}

Este estudio exploró qué debe saber y saber hacer un profesor de niños con talento cuando está implementando el programa PENTA UC Escolar. Este estudio incluyó una muestra de 18 educadores directamente involucrados en los procesos de implementación de este programa de enriquecimiento. Los profesores establecieron puentes entre lo verbalizado y su práctica pedagógica reconociendo los saberes y saberes hacer, como dos esferas del conocimiento necesarias para implementar este programa. Los resultados muestran que éstas atraviesan cinco dimensiones: planificación, implementación, evaluación, clima de aprendizaje y trabajo colaborativo, las que en su conjunto permiten al profesor aplicar una instrucción diferenciada considerando ritmos de aprendizaje y características de niños con talento. Además, confirma la necesidad de considerar estas esferas de conocimiento en los programas de preparación de profesores.

Palabras clave

Saberes, saberes hacer, profesores, educación de talentos.

Palabras clave descriptores

Personal docente, niños superdotados, escuela, investigación cualitativa. 
When we talk, in general, of providing quality education, we must think of how relevant it is to implement a curriculum which takes into consideration the needs of students, and to rely on professionals who can also do the same. It is unthinkable to implement a program in talented education that provides academically talented children with the space for intellectual and social enrichment without recognizing the importance of the training of teachers in this field of education (Croft, 2003; Feldhusen, 1997; Hansen \& Feldhusen, 1994); particularly, if we do not think about the know and know-how that the teachers require in order to provide talented children with high-quality education.

Countries such as the United States, Australia, the United Kingdom, Israel and Spain, among others nations, have invested material and human resources in implementing programs that provide quality education to children identified as gifted (Monks \& Pflüger, 2005). These initiatives, which originated nearly three decades ago from both state or private entities, have enhanced a generation of training programs for professionals (Cropley \& McLeod, 1986; Eyre \& Wilson, 2002; Matthews \& Foster, 2005; Oshrat \& Shur, 2002), and in some countries they have even nurtured the construction of training standards in talented education (VanTassel-Baska \& Johnsen, 2007; National Quality Standards in Gifted and Talented Education, 2005).

In Latin America, we find isolated initiatives in this direction, stemming from the state or universities, which nearly two decades ago marked the beginning of this tendency that remains until today. The issue of educating gifted children is new in some of our countries, for example in Bolivia, where the state has set in motion a process of awareness and recognition of these children in their school system and has committed in an effort to work with teachers and educational institutions in order to achieve effectiveness (Cambio, 2010). In other countries this process has taken longer, as is the case of Peru, Brazil, Colombia, Mexico and Chile. In the first four of them, the experiences have emerged within the state as an orientation or a public policy (Ministerio de Educación de Colombia, 2006; Rodríguez, 2006, Benavides, Maz, Castro \&
Blanco, 2004). In Chile, the legal framework does not consider explicit public policies regarding the education of talents, but it is recognized by the education system and university research centers which seek to create educational opportunities capable of meeting the educational needs of this population of students (Benavides et al, 2004; García-Cepero $\&$ Proestakis, 2010). Thus, enrichment programs have been created in six universities of Chile ${ }^{1}$, and some experiences that take into account the special educational needs of gifted children have been implemented inside regular schools (GarcíaCepero \& Proestakis, 2010; PENTA UC, 2009). These programs are not sufficient to cover the large number of talented children that may exist within the school-age population of a country, if we take into account in quantitative terms that $10 \%$ of the population has talent, and this talent could be expressed in different degrees and fields of human activity (Gagné, 2003). In Chile, there are 350.000 talented children that require differentiated education and of which only $1.4 \%$ are currently receiving it; mainly from enrichment programs offered by universities and, to a lesser extent, by some regular educational institutions (Bralic, 2010; PENTA UC, 2009). That is, $98.6 \%$ of talented children currently attending the regular classroom are not receiving a quality education that takes into consideration their educational needs.

If we consider, as Bralic asserted (2010), that "they are talented every day, every week" and those who participate in enrichment programs "are treated as such only one sixth of their time" (p. 34) the question rises: How can the educational needs of a whole population of talented children be supported? Talent education, involves proposing talent identification models, enrichment programs, educational policies that benefit the population of talented children, as well as training teachers so that they can support the needs of talented students even inside educational institutions (Cabrera-Murcia, 2011;

1 Pontifica Universidad Católica de Chile, Pontificia Universidad Católica de Valparaíso, Universidad Católica del Norte, Universidad de Concepción, Universidad de la Frontera, Universidad Austral de Chile. 
Guzmán, 2010; Renzulli \& Reiss, 2002). This study deepened in the know-how and know-how that one group of teachers indicated as necessary in order to promote the academic and social development of talented children.

This study was specifically undertaken with teachers who implemented the enrichment program PENTA UC School. This program enhances children's talent from the first level of basic education ( $1^{\text {st }}$ through $4^{\text {th }}$ grade) within the regular school system. It is based on the enrichment curriculum in the Language and Mathematics areas, in which their analytical, creative, and practical abilities are enhanced (PENTA UC, 2009). In addition, the implementation of this program brought about a novel training method for teachers in said curriculum as well as in topics related to talented education. This pilot program has enabled the collection of valuable information on the subject matter of this article.

\section{Background}

The characteristics and competences of teachers of gifted children were reported some decades ago in Anglo-Saxon culture. This culture indicated that the teacher of gifted children requires a special set of knowledge and skills conducive to the progress of these children through the application of complex and challenging content (Croft, 2003). Some studies have shown consensus regarding some particular characteristics that characterized teachers of gifted students: significant intelligence, cultural and intellectual interests, high expectations of achievement, enthusiasm, imagination, commitment to gifted students, self-confidence, awareness of the individual differences and emotional needs of their students, and strong communication skills (Bishop, 1968; Heath, 1997; Milgram, 1979).

The different characteristics and competences a teacher must have, obtained from empirical or theoretical articles and reports reviewed, can be associated with the know and know-how-to-do categories. For example, empirical studies have revealed that the students give more importance to the personal social behavior of teachers. Being openminded and easy-to-talk-to, enthusiastic or willing to facilite the development of a shared language of learning, (Abel \& Karnes, 1994; Davalos \& Griffin, 1999; Landvogt, 2001; Matthews \& Kitchen, 2007; Mönks \& Wagner, 2002) can also be considered a necessary know-how-to-do in order to make the class an affirmative place where the talent potential of children may be nourished. In some other studies, the teachers have pointed out that knowing the needs of gifted children in cognitive and affective domains; the different types of experiences that nurture their potential; and having skills to apply group process, teaching methods and techniques -questioning some professional predispositions (Chan, 2001; Daugherty, 2010; Davalos et al., 1999; Joffe, 2001; Matthews et al, 2007; McGinty, 2010; Miranda \& Landmann, 2001) - are necessary elements to enhance children's abilities. These elements configure some relevant know and know-how forms in the professional exercise and, of course, in the training of teachers for talented education.

Descriptions obtained from theoretical articles produced in Anglo-Saxon and Latin American cultures also show the importance given to know and know-how in this process. Thus, knowing the characteristics of their students, generating challenging environments which are not stressful, with the ability to link processes with outcomes or products, facilitators of the learning processes of their students are able to apply different methodological alternatives and to create strong relationships and a positive classroom atmosphere (Croft, 2003; Genovard, Gotzens, Badía \& Dezcallar, 2010; Grau \& Prieto, 1996; Metrau, 2010; Wolfensberger, 2008).

We can also find experiences and reports that show and discuss the role played by know and know-how in the process of training for teachers (Apss, 2011; Callahan, Cooper \& Glascock, 2003; Daugherty, 2010; Hoffer, 2011; Matthews \& Foster, 2005; Mönks et al. 2002; National Association for Gifted Children-NAGC/Council for Exceptional Children; 2006; Sueker, 2011). For example, NAGC (2006) addresses the need to know and understand the characteristic of talented children in different domains (know) as well as their abilities (know-how) to implement differentiated curricula, instructional challenges, motivation and other aspects, which 
are necessary for those who work in this field of education. These were grouped in ten standards that show the Knowledge and Skill Standards required for a teacher working with gifted and talented children, namely, foundations; development and characteristics of learners; individual learning differences; instructional strategies; learning environments and social interactions; language and communication; instructional planning; assessment; professional and ethical practice; and collaboration, are the standards created to address the broad disparity in teaching training in the United States (Van Tassel-Baska \& Johnsen, 2007). The proposal is that these standards should permeate different gifted education programs (short courses, modules at university or Master of Science levels in gifted education) for the competence certification of teachers of gifted children.

Very little evidence has been found on a review of Latin American literature that supports or gives substantive evidence to boost the know and know-how that characterize a teacher of talented children in programs that are implemented or that are underway.

There are some experiences and reports undertaken by government institutions that have been working in programs or on a pedagogical model aiming at enhancing competences in students with great abilities or talent, and some explicit characteristics of teachers. These show some predispositions, personal and professional features, proved necessary in any process of formation for teachers (Casillas, 1996; Rodríguez, 2006).

Reports about the quality of courses of two enrichment programs in Chile could be linked to know and know-how. Although these reports show the perspectives of two different educational actors, we can say that these are similar and complementary. First, from the perspective of the teachers of PENTA UC program, the reports indicate that, besides the particular characteristics of the student, it is necessary to train a teacher who uses appropriate learning methods and motivation strategies, who makes questions that allow students to apply learned lessons to new situations, that stimulates the active participation of students, and is highly motivated to teaching (Bralic, Seguel, Real, et al, 2005). Second, from the perspective of students who participated in BETA program in the last three years, the quality of courses depends on the fact that teachers use different methodological strategies, encourage creative thinking, take into consideration cognitive challenges in their learning, and certainly know the contents and have expertise in the topic. In addition, teachers should create a good learning environment, in which they must have high performance expectations for students, ensuring their learning (Conejeros, 2010). This data endorses the need that teachers possess knowledge and be able to apply it in a context of learning with talented children, as well as the need for standards that permit preparing teachers in this area.

Empirical evidence suggests that teachers should be trained to create a stimulating atmosphere for their students, to know about general and specific characteristics for enhancing their students' abilities. Furthermore, teachers should know instructional strategies to encourage students in their learning process (Blumen, 2000). The same author warns there is a need to establish permanent training for and continuous monitoring of teachers if we wish to meet the needs of the highly able children. If teachers do not receive monitoring and coaching after training, the achievements made for the students are likely to decrease. It is therefore necessary "to establish permanent training follow-up activities for teachers" (Blumen, 2000, p. 101).

A greater understanding of how educators are trained to work with talented students will allow us to propose criteria and guidelines for teachers' training in talented education. In particular, the present study was conducted to discover forms of knowing and knowing-how that teachers must possess in order to implement this program with talented students, based on the experience of the participants involved in this process. For this reason, our analysis focused on the discourse produced by teachers who implemented it as a pilot experience for two consecutive years. These data were obtained from self-reporting and have been contrasted with 
demonstrable and substantive evidence extracted from direct observation of the teachers' pedagogical practice and reports given by their students, who have worked directly with those teachers. Particularly, with this research we sought to collect information on know and know-how in which we must focus if we are to build standards that permit the training of teachers who want to work in the field talented education.

\section{Method}

\section{Participants}

Eighteen teachers, sixteen women and two men implemented the enrichment program PENTA UC School in the school levels from $1^{\text {st }}$ through $4^{\text {th }}$ grade for two consecutive years. Participants were between 22 and 60 years old $(M=39.4)$. All teachers were from the same municipality located in the Metropolitan Region of Santiago, Chile. Prior to implementation, they followed a course of 250 hours, conducted in two rounds over 2007 and 2008. In this course they received preparation in topics such as knowledge of cognitive and socioemotional characteristics of children with talent and in methodologies and strategies appropriate for applying the program.

\section{Instruments}

\section{Survey using open questions}

Teachers replied to an open question. In their answer they indicated the characteristics and competences that, in their view, a teacher that works applying enrichment programs for PENTA UC Escolar should have. This was self-administered and was applied to the finished project, once the process of implementing the program had ended.

\section{Semi-structured interview}

Eight teachers from the group of participants were selected for interview. The criteria used for selection were in what areas of the curriculum training had been received and implemented (four teachers of language and four teachers of mathematics) and the version of the program that received preparation (four teachers for each one). These teachers were invited to participate in this second process through a personal letter, in which they were explained the importance of establishing a dialogue, through which they could report their experiences and those aspects that they considered relevant for understanding what they must know and know-how to do.

\section{Classroom observations}

This rubric allowed to evaluate the percentage of use of the different dimensions considered relevant in the performance of teachers who work with talented children, and to gather information on the actions and/or behavior of students.

\section{Satisfaction survey}

This instrument has the characteristic of being self-administered and was responded to by 151 students who studied during the last semester of this program's implementation. Ten items observed the students' perceptions on teaching styles and the use of different teaching strategies; and established relationships between them. This survey used a three-level scale, from 1 -when the teacher has never used a particular action- to 3 -when it is always used by the teacher.

\section{Data analysis}

Two undergraduate students transcribed all answers provided to the open questions, such as in the semistructured interviews. The information obtained with both instruments was analyzed qualitatively; it was read, coded and classified using open coding. To ensure the reliability of the data in the current study, two judges, psychologists, education experts in talent, and one not directly related to this project were in charge of codifying all data. A high level of inter-rater agreement was seen for the categories and topics that emerged. The differences that 
emerged were reviewed by the investigator and the judges, and compared to the data that was obtained from the original discourse. In order to find the level of reliability of the data, and triangulate the information with the judges, we contrasted the information obtained in interviews with the characteristics and competences written in the open questions. In addition, with this information, a descriptive analysis allowed us to discover the frequency of emerging dimensions and themes.

Subsequently, with the dimensions obtained and the exemplifications that were close to the teachers' discourse, the investigator retrieved the know and know-how that teachers considered necessary in their practice. After this, grouping was triangulated with the vision of two educational psychologists that worked in the project from its inception. For this triangulation the psychologists used a rubric to evaluate the level of agreement or disagreement in relation to the classification proposal. After the researcher spoke to each of them about this work, their perceptions of the product and possible difficulties in its interpretation, both judges showed their agreement in the classification proposal.

Two educational psychologists undertook classroom observations of teachers who implemented the program and calibrated their observations in order to recognize similarities in the application of their observations and to reduce differences. A reliability analysis on data obtained from the survey conducted on students was also carried out. The alpha obtained $(\mathrm{r}=0.79)$ indicates a good internal consistency. The data collected with these instruments was also analyzed quantitatively. Descriptive analysis was performed in order to contrast indications made by teachers with direct evidence from their teaching practice. Although the number of participants in this study is relatively small and targeted a group of teachers who have been trained and have worked to implement the program, it is the richness of the data obtained from the contrast between verbalized and implemented knowledge which constitutes a significant contribution to what teachers know and should know how to do in order to implement this enrichment program.

\section{Results}

A first analysis of the discourse produced by teachers both in the open questions and in the semistructured interviews identified 110 conceptual categories. They were grouped in more abstract categories based on their conceptual similarity. From this, five dimensions emerged that shape the know and know-how of the teachers that implemented this program. Those dimensions are planning, implementation, evaluation, learning environment, and collaborative work. In conjunction, they characterize a teacher that knows his or her discipline, a professional who is able to take on challenges and to project them onto his or her students; a flexible, innovative individual, with a great sense of commitment, responsibility and knowledge of his or her students. On the other hand, each one of these dimensions allows teachers to apply a differentiated instruction for talented children and gives them the possibility to work with themes, concepts and issues that constantly challenge the students, while taking into consideration their particular learning pace and characteristics.

These dimensions and the corresponding exemplifications offered by the teachers were grouped considering the know and know-how criteria. For this purpose, two educational psychologists, different from those involved in the first process but who worked in the implementation of the program, evaluated the classification. Once again, they were highly consistent with each other, indicating that know and know-how were found to correspond to what was said in the discourse of teachers.

This analysis reveals a great deal of information about the importance that teachers give to five dimensions in their work and especially about how to nurture the implementation of the curriculum. "Know and know-how" offers important guidance for educators when applying this program. All dimensions are required in both spheres of knowledge for them to adequately function in practice. To know traverses all dimensions and corresponds to know how to do. These dimensions nurture all the pedagogic processes that are produced in the classroom. For example, you are 
required to understand the characteristics in the student's cognitive and socio-emotional domains (know) and to plan and implement (know-how) more effective instruction in order to provide instructional differentiation and to respond to the needs of the learners. Table 1 show the knowledge obtained from the analysis of discourse of the teachers. The first column shows the know that teachers think must be possessed to imple- ment this program. The second column indicates the dimensions in which such "knowledges" are shown or were viewed in the practice they used. Finally, the third column shows the "know hows" that nurture other "knows" and their respective dimensions. The following tables (2 and 3) show some examples of discourses of teachers, with the objective of clarifying and exemplifying know and know how in the teachers' own words.

TABLE 1

Know and Know-how of teachers in PENTA UC Escolar Program

\begin{tabular}{|c|c|c|}
\hline Know & Dimensions & Know-How \\
\hline \multirow[t]{2}{*}{$\begin{array}{l}\text { Knowing the cognitive and socio-affective } \\
\text { characteristics of children and young } \\
\text { people with academic talent. }\end{array}$} & Evaluation & $\begin{array}{l}\text { Suggesting ways of evaluation that allow } \\
\text { assessment of the progress of their students. } \\
\text { Assessing their students on an ongoing basis. }\end{array}$ \\
\hline & & $\begin{array}{l}\text { Using active methods in the development of skills } \\
\text { that allow them to foster the development of skills }\end{array}$ \\
\hline
\end{tabular}

Differentiating the analytical, creative and practical skills in a given context.

Knowing methodological strategies to encourage a process of active and differentiated learning and teaching.
Differentiating objective, ability and activity in the session indicated within the curriculum.

Knowing the general structure of each manual.

Having a theoretical domain of the content of the curriculum in the Language and Mathematics programs in their students.

Using questioning techniques that challenge the skills of talented students.

Implementation

Providing differentiated activities within the group according to the abilities and learning styles of its students.

Implementing strategies for individual and team work to encourage student-student and studentteacher interaction, in developing their students' skills.

Emphasizing the development process over the content.

Selecting, modifying or including new activities in the development of the lessons, taking into consideration the central purpose of the manual and the skills to be developed.

Planification Making design adjustments to their lessons, according to the characteristics of gifted children. Generating learning (activities) in which the cognitive challenge is the articulating axis. Promoting the development of analytical, creative and practical skills in the preparation and implementation of class sessions.

Establishing strong relationships with talented students.

Learning climate Guiding students according to their interests and needs.

Teaming up with other professionals.

Establishing appropriate relationships and

Collaborative work communication channels with other actors in the process (parents, teachers, students, etc.).

Source: own Work. 
TABLE 2

Example of discourse of the teachers about "know"

\begin{tabular}{|c|c|}
\hline Know & Examples of the discourse of teachers \\
\hline $\begin{array}{l}\text { Knowing the cognitive and socio-affective } \\
\text { characteristics of children and young people } \\
\text { with academic talent. }\end{array}$ & $\begin{array}{l}\text { "...I feel it is important for a teacher in the training process, as well } \\
\text { as awareness of the issue of education purely because, uh... you go } \\
\text { there with that responsibility, to help bring up these children..." } \\
\text { (Interviewee, 1) }\end{array}$ \\
\hline $\begin{array}{l}\text { Differentiating the analytical, creative and } \\
\text { practical skills? in a given context. }\end{array}$ & $\begin{array}{l}\text { "...Just develop the three skills and engage the children in the process, } \\
\text { well I always worry that children participate enough but a bit more, } \\
\text { more firmly, with more confidence ... encouraging the children more, } \\
\text { also assigning them practical work and letting them develop their } \\
\text { creative skills ..." (Interviewee, 2) }\end{array}$ \\
\hline $\begin{array}{l}\text { Knowing methodological strategies to } \\
\text { encourage a process of active learning and } \\
\text { differentiated teaching. }\end{array}$ & $\begin{array}{l}\text { "... For me, it was a contribution to methodology, how to work with } \\
\text { inductive thinking, the way children think through the questions, } \\
\text { how to give feed-back, meta-cognition. Although these concepts were } \\
\text { revised in a different way, I retrieve this learning when working with } \\
\text { gifted children" (Interviewee, 6). }\end{array}$ \\
\hline $\begin{array}{l}\text { Differentiating objective, ability and activity } \\
\text { in the session raised within the curriculum. }\end{array}$ & $\begin{array}{l}\text { "A clear objective is key ... the organization of the sessions was } \\
\text { adequate, the annexes too, because they were the form to bring } \\
\text { the content down to the children. In some cases I had to make up } \\
\text { activities, because I felt that it was necessary, but since the objective } \\
\text { was clear I could do it..". (Interviewee, 7). }\end{array}$ \\
\hline $\begin{array}{l}\text { Knowing the general structure of each } \\
\text { manual. }\end{array}$ & $\begin{array}{l}\text { "...The contents are clearly understood, the activities and support } \\
\text { material to work with children,are also clear and... this material is very } \\
\text { practical..." (Interviewee, 2). }\end{array}$ \\
\hline $\begin{array}{l}\text { Acquiring a theoretical mastery of the } \\
\text { content of the curriculum in Language and } \\
\text { Mathematics of the program. }\end{array}$ & "Mastery of content, I feel that this is crucial" (Interviewee, 7). \\
\hline
\end{tabular}

Source: own Work.

These "knowledges" that characterized the implementation of PENTA UC Escolar Program are endorsed by the results obtained from the observation of the teachers' practice. These data indicate the percentage of use of those dimensions recognized as important in a class for talented children. The cognitive challenge is used in $82 \%, 75 \%$ in active methodologies, $92 \%$ in positive learning climates, $82 \%$ in formative evaluation, and $86 \%$ in the efficient use of time. All these Features agree with the characteristics of a class for talented children.

The descriptive data shows that the teachers provide the students with tasks that escalate in complexity and challenge, with differentiated opportunities, adjusted for each student taking into consideration their particular needs and characteristics. This is possible if the teachers use active methodologies that allow for the construction of knowledge in some occasions in the form of the individual, the group or both, and where the teacher and students work together flexibly. In this case, the assessment is a process that is included throughout the teaching process, which consists of formative assessment at the start of the course, during the course of the class, and at the end. This conception is relevant when talking about cognitive challenges and active methodologies, because the instruction and the general process of teaching will be adjusted after learning the students' abilities and needs. It is important to point out that these changes allow for a differentiated instruction for all the students.

Finally, the data also shows that the teachers obtained a higher percentage in keeping a positive climate for learning and an adequate use of the time. The teacher may use different strategies 
TABLE 3:

Example of discourse of the teachers about know how to do

Know how
Suggesting ways to allow for an assessment of the progress of
their students. Assess their students on an ongoing basis. Using
active methods in the development of the lessons allows to foster
the development of skills in students.

Using questioning techniques that challenge the skills of talented students.

Providing differentiated activities within the group according to the abilities and learning styles of the students.

Implementing strategies to individual and team work to encourage student-student, student-teacher interaction while developing their students' skills. Emphasizing on the development process over content.

Selecting, modifying or including new activities in the development of meetings considering the central purpose of the manual and the skills to be developed. Making adjustments to the design of lessons, according to the characteristics of gifted children. Generating learning (activities) in which the cognitive challenge is its articulating axis. Promoting the development of analytical, creative and practical skills in the preparation and implementation of classes.

Teaming up with other professionals. Establishing appropriate relationships and communication channels with other actors in the process (parents, teachers, students, etc.).

Source: own Work.

to build a space in which the students feel safe and challenged to learn, where the interpersonal relationships are more fluid, not unidirectional. All the data also have a direct relationship with the observations made to the students in the same class. The $90 \%$ of them had a central role in the learning process, they are more active and work together with the teacher and their classmates to accomplish goals, and occasionally in an individual manner or in groups.

The data obtained from the evaluation of the students showed that the teachers had used one active dynamic in the development of the class where the student had one active role. The mean values obtained showed that the students agreed in indicating that the teachers explained clearly $(M=2.8)$, giving answers to the questions posed
Examples of the discourse of teachers

"a teacher who has the flexibility to change the lessons, to modify activities depending on depending on the circumstances the moment" (Interviewee, 3).

"...The other difference is that one can reach children with talent, that is, to me I can start teaching gifted children from the basics and build a huge pyramid, whereas with the other children I had a lot of expectations and thought that the class was going to be great, spectacular, and maybe it went a step forward, two steps and if I turned the other way ask again, they would not remember anything..." (Interviewee, 3).

"there are fundamental differences in how one deals with the content, there's the basis, I think if you are sitting here a basic teacher will tell you, it will be the methodology, how do I address the content, how do I address skill development ...".

“...Sometimes, I was not very sure about my planning or about the concepts, but I would talk to another colleague and then, together, we would work on their reformulation or clarification..." (Interviewee, 2). to them $(M=2.6)$, showing any mistakes in directions of thought $(M=2.7)$, building a position where they could ask questions and think about them $(M=2.6)$, using different methodological strategies for development abilities and expanding knowledge $(M=2.7)$. Also, the students agreed that the teachers created a climate of positive learning $(M=2.7)$, because they recognized the active role of students, allowed their participation and had a good relationship with all students in the class $(M=2.6)$. Teachers and students enjoyed the class.

\section{Discussion}

The intention of this study was to determine those 'know' and 'know-how' that the teachers consider important when working with talented students and, 
in particular, in this program. Despite the evidence that was presented here, which proceeded from a qualitative study -remembering that this type of study cannot be generalized-it is important to emphasize that these results are endorsed with the comparative analysis undertaken with direct practice.

First, it is important to highlight that our findings demonstrate the consistency between teachers' discourse and practice. In other words, teachers were able to demonstrate what they said while their teaching practices were under direct observation. Secondly, these findings reinforce the need for providing training to regular teachers who work with students with academic talent, for possessing a single-area knowledge and a great motivation for teaching these students are not sufficient conditions to implement such programs.

For teachers, the know translated into the domain of the discipline as well as into certain methodologies for applying a differentiated education are important to deploy the necessary actions in practice to enable them to effectively provide students with a learning process that challenges and empowers them, while developing their skills. The basis for the implementation of the program is possessing solid knowledge -at the conceptual level- of the subjects that will be taught; of processes (skills to enhance); of teaching methodologies; instructional strategies and evaluation systems (Know). A deep knowledge in these areas, allows the construction of know-how that translates into effective practices in the classroom (know-how).

In the first place, a comparison between the results of this research and those presented by Van Tassel-Baska et al. (2007), allows us to establish a direct relationship between the standards present by the authors and the importance given by teachers to the different dimensions in which to demonstrate know and know-how that are necessary for the practical PENTA UC School program. These spheres of knowledge are specifically related to the development and characteristics of learners, individual learning differences, instructional strategies, learning environments and social interactions, instructional planning, assessment and collaboration. Secondly, they emphasize that there must be a certain level of consistency between the knowledge and skills that underlie them. That is, it requires knowing what and why (know) and then knowing how to apply (know how) said knowledge.

Practical applications of this study point to the traning that teachers should be receiving in order for them to apply this type of program. They need to receive training in both spheres of knowledge and their subsequent implementation. It is also necessary to work alongside these teachers during their practice in order to evaluate how they incorporate their knowledge into practice and how they can be oriented so as to make this intervention effective. In this sense, our results agree with those of Blumen (2000), who stated the importance of monitoring and coaching the teachers' practices in training.

A second implication refers to the initial training of teachers. The idea that that we should provide quality education to all students and even respond to their needs is widely accepted, but how can a pre-service teacher consider the needs of students, if they are only trained to work with those who are positioned within the "standard"? Given these findings, we suggest incorporating some of these know and know how in the curricula of the academic programs that instruct professionals in education. Taking into consideration these spheres of knowledge in talent education from college, will enable pre-service teachers to recognize and respond in a more realistic way to the individual needs of their students.

Finally, we believe these findings obtained by teachers themselves may be a contribution to the construction and validation process of public policies that promote quality education for all children, including those with talent. We share with Guzmán (2010) the believe that if we look at educational policies through the lens of talent education, we will be able to provide a differentiated instruction that promotes particular needs of all talented students and allows them to receive a more challenging and higher quality education. As we indicated in the conceptual framework, there is a public policy related to education of talented children in many Latin American countries. The next step is to generate at the interior of each Ministry of Education 
specific criteria for the certification of teachers who work with talented children, as well as to formulate guidelines that promote the implementation of initiatives aimed at addressing the education of talents. According to Bralic (2010), by implementing educational alternatives such as flexible groupings, total or partial acceleration programs, we will be able to promote talent development in our students.

\section{References}

Abel, T. \& Karnes, F. A. (1994). Teacher's preferences among the lower socioeconomic rural and suburban advantaged gifted students. Roeper Review, 17 (1), 52-57.

Apps, K. (2011). Relationships between teachers' perceptions of gifted program status and instructional choices. (Doctoral Thesis). Retrieved from ProQuest Dissertations and Thesis database (UMI $\left.\mathrm{N}^{\circ} 3465945\right)$.

Arancibia, V., Contreras, J., Cabrera, E. P. \& Lacerna, P. (2009). Marco Curricular Modelo PENTA UC Escolar. Unpublished manuscript, Centro de Estudios y Desarrollo de Talentos, Pontificia Universidad Católica de Chile, Santiago, Chile. PENTA UC

Benavides, M., Maz, A., Castro, E. \& Blanco, R. (Eds.) (2004). La educación de niños con talento en Iberoamérica. Santiago (Chile): OREALC/ UNESCO. Retrieved from http://unesdoc.unesco. org/images/0013/001391/139179s.pdf

Bishop, W. (1968). Successful teachers of the gifted. Exceptional Children, 34 (5), 317-325.

Blumen, S. (2000). Identification of and Differentiation for the Highly Able in Lima. (Doctoral Dissertation). Retrieved from: http://dare.ubn.kun.nl/ handle/2066/18878

Bralic, S. (2010). Reflexiones sobre el sistema escolar y la promoción del talento. En: García-Cepero (Ed.). Talentos en el Bicentenario. Educación para el desarrollo de estudiantes sobresalientes. Antofagasta: Centro de Investigación y Desarrollo de Talento DeLTA-UCN, Universidad Católica del Norte.

Bralic, S., Seguel, X., Real, F., Beuchat, C., Chuaqui, H., Loëb, B., et al., (2005). Resultados Calidad de los cursos primer y segundo semestre 2005. Centro de Estudios y Desarrollo de Talentos-PENTA UC.
Pontificia Universidad Católica de Chile. Santiago de Chile: Chile.

Cabrera-Murcia, E. P. (2011). Entretejiendo los aprendizajes: desde el programa de perfeccionamiento de la pasantía PENTA UC a la práctica pedagógica. Magis, Revista Internacional de Investigación en Educación, 4 (7), 105-120.

Callahan, C., Cooper, C. \& Glascock, R. (2003). Preparing teachers to develop and enhance talent: The positions of national education organizations (ERIC Document Reproduction Services $N^{\circ}$ ED477882).

Casillas, M. A. (1996). Capacitación a docentes en el desarrollo de potenciales: una estrategia para elevar la calidad de la Educación. Retrieved from http:// educar.jalisco.gob.mx/06/6casilla.html

Chan, D. (2001). Characteristics and competencies of teachers of gifted learners: The Hong Kong teacher perspective. Roeper Review, 23 (4), 197-202.

Chen, Z. \& Siegler, R. S. (2000). Intellectual development in childhood. In R. J. Sternberg (Ed.), Handbook of Intelligence. Cambridge UK: Cambridge University Press.

Conejeros, M. L. (2010). Estrategias para mejorar la calidad y equidad educacional. In García-Cepero (Ed.), Talentos en el Bicentenario; Educación para el desarrollo de estudiantes sobresalientes. Antofagasta: Centro de Investigación y Desarrollo de Talento DeLTA-UCN, Universidad Católica del Norte.

Croft, L. J. (2003). Teachers of the gifted: Gifted teachers. In N. Colangelo \& G. Davis (Hrsg.), Handbook of gifted education. New York: Allyn and Bacon.

Daugherty, M. (2010). Supporting the Needs of Gifted Students: The perspectives, Perceptions, and Experiences of General Education Teachers (Doctoral Dissertation) Retrieved from ProQuest Dissertations and Thesis database. (UMI N ${ }^{\circ}$ 3412079).

Davalos, R. \& Griffin, G. (1999). The impact of teachers' individualized practices on gifted students in rural heterogeneous classrooms. Roeper Review, 21 (4), 308-314.

Gagné, F. (2003). Transforming Gifts into Talents: The DMGT as a Developmental Theory. In N. Colangelo \& G. A. Davis (Eds.), Handbook of gif- 
ted education (3rd ed.) (pp. 60-74). Boston: Allyn and Bacon.

Gallagher, J. (2003). Issues and challenges in the education of gifted students. En N. Colangelo \& G. A. Davis (Eds.), Handbook of Gifted Education (3rd Edition), (pp.11-23). Boston: Allyn and Bacon.

García-Cepero, M. C. \& Proestakis, M. N. (2010). Perspectivas de atención a los estudiantes con talento académico. Una visión global. En García-Cepero (Ed.), Talentos en el Bicentenario; Educación para el desarrollo de estudiantes sobresalientes. Antofagasta: Centro de Investigación y Desarrollo de Talento DeLTA-UCN, Universidad Católica del Norte.

Genovard, C., Gotzens, C., Badía, M. P. \& Dezcallar, M. T. (2010). Los profesores de alumnos con altas capacidades. REIFOP, 13(1). Retrieved from http:// www.aufop.com

Guzmán, M. I. (2010). Políticas educativas para el desarrollo del talento académico en Chile. En GarcíaCepero (Ed.), Talentos en el Bicentenario; Educación para el desarrollo de estudiantes sobresalientes. Antofagasta: Centro de Investigación y Desarrollo de Talento DeLTA-UCN, Universidad Católica del Norte.

Grau, S. \& Prieto, M. (1996). La formación de profesores de alumnos dotados. Revista Interuniversitaria de Formación del Profesorado, 27, 127-139.

Hansen, J. B. \& Feldhusen, J. F. (1994). Comparison of trained and untrained teachers of gifted students. Gifted Child Quarterly, 38(3), 115-121.

Heath, W. (1997). What are the most effective characteristics of teachers of the gifted? (ERIC Document Reproduction Service $N^{\circ}$ ED411665).

Hoffer, S. (2011). A study of the perceptions of pre-service and in-service educators on best practices for gifted students (Doctoral Thesis, Indiana University of Pennsylvania). Retrieved from: http://dspace. lib.iup.edu:8080/dspace/bitstream/2069/366/1/ Stacie+Nowikowski.pdf

Joffe, W. (2001). Investigating the acquisition of pedagogical knowledge: Interviews with a beginning teacher of the gifted. Rooper Review, 23(1), 219-226.

Landvogt, J. (2001). Affecting eternity: teaching for talent development. Roeper Review, 23 (4), 190-196.

Matthews, D. \& Foster, J. (2005). A Dynamic Scaffolding Model of Teacher Development: The Gifted
Education Consultant as Catalyst for Change. Gifted Child Quarterly, 49 (3), 222-230.

McGinty, P. (2010). The influence of teacher characteristics on preference for models of teaching (Doctoral Dissertation, Faculty of the Usc Rossier School of Education University of Southern California). Retrived from http://digitallibrary.usc.edu/ assetserver/controller/item/etd-McCord-3573.pdf

Mettrau, M. (2010). Programas académicos para la formación de profesores de alumnos con superdotación y talento. REIFOP, 13(1), Retrieved from http://www.aufop.com

Milgram, R. (1979). Perception of Teacher Behavior in Gifted and Nongifted Children. Journal of Educational Psychology, 71 (1), 125-128.

Ministerio Educación Nacional (2006). Orientaciones para la atención educativa a estudiantes con capacidades o talentos excepcionales. Retrieved from http://www.areandina.edu.co/bienestar/documentos/LINEAMIENTOS_TALENTOS_EXCEPCIONALES.pdf

Miranda, E. \& Landmann, R. (2001). Gifted teachers creating gifted Classroom: One exceptional teacher, one exceptional classroom. Rooper Review, 23 (4), 230-234.

Mönks, F. J. \& Wagner, H. (Ed.). Development of Human Potential: Investment into our future. Proceedings of the 8th Conference of the European Council for High Ability (ECHA), 133-134. Boon: Germany.

National Association for Gifted Children/Council for Exceptional Children (NAGC-2006). NAGCCEC Teacher Knowledge \& Skill Standards for Gifted and Talent Education. Retrieved from: http://www.nagc.org/uploadedFiles/Information and_Resources/NCATE_standards/final\%20standards\%20(2006).pdf

Renzulli, J. \& Reis, S. (1997). What is Schoolwide Enrichment? And How Do Gifted Programs Relate to Total School Improvement? Gifted Child Today, 25(4), 18-25.

Rodríguez, M. (2006). La atención a niños con facultades talentosas sobresalientes en el marco de un programa estatal. Paper presented at the VI Congreso Iberoamericano de Superdotación, Talento y Creatividad, Fycomundit, Mar del Plata, Ar- 
gentina. Retrieved from www.paenftsperu.com/ conferencias/02sep_conf.doc

Sueker, C. (2011). A Phenomenological Exploration of Teacher Training Regarding Academically Advanced/ High-Ability Students (Doctoral Thesis). Retrieved from ProQuest Dissertations and Thesis database. (UMI N $\left.{ }^{\circ} 3453858\right)$

VanTassel-Baska, J. \& Johnsen, S. (2007). Teachers Education Standards for the Field of Gifted Education:
A Vision of Coherence for Personnel Preparation in the 21st Century. Gifted Child Quarterly, 51, 182.205

Wolfensberger, M. (2008). Six Habits of Highly Inspiring Honours Teachers. In L. Clark \& J. Zubizarreta (Eds.) Inspiring Exemplary Teaching and Learning: Perspectives on Teaching Academically Talented College Students. National Collegiate Honors Council: Lincoln, NE. 
